\title{
Recent patents in cloning
}

\begin{tabular}{ll} 
Patent \# & Subject \\
\hline US 6001612 & $\begin{array}{l}\text { A method for cloning a nucleic acid sequence into a double- } \\
\text { stranded DNA vector using two separate polymerase chain } \\
\text { reactions. It does not require the use of restriction endo- } \\
\text { nucleases to digest the ends of the PCR products, which } \\
\text { is often an inefficient process. }\end{array}$ \\
US 6001600 & $\begin{array}{l}\text { Isolated polynucleotides encoding a novel Staphylococcus } \\
\text { aureus response regulator protein; useful for identifying } \\
\text { bacterial proteins expressed during infection, as inhibitors } \\
\text { in antibacterial therapy, and as hybridization probes for } \\
\text { RNA, cDNA, and genomic DNA to isolate full-length } \\
\text { cDNAs and genomic clones encoding the S. aureus } \\
\text { WCUH29 novel response regulator protein. }\end{array}$
\end{tabular}

WO 9961604 A new gene-trapping vector for Drosophila melanogaster genes, used for the cloning and functional analysis of novel genes.

WO 9958724 The synthesis of nucleic acids using a ribonuclease enzyme to eliminate RNA background in synthesis reactions for the cloning, amplification, and sequencing of nucleic acids. The use of ribonucleases results in proper amplification and elongation of target DNA templates as wel as an increase in the amount of synthesized product and increased product length.

WO 9958684 Novel peptides useful as vaccines for Moraxella catarrhalis infections such pneumonia, and as hybridization probes for RNA, cDNA, and genomic DNA to isolate fulllength cDNAs and genomic clones encoding BASB020 and to isolate cDNA and genomic clones of other genes that have high sequence identity to BASB020 gene.

JP 11304666 A microorganism sample-handling tool with a microhydrophilic area provided on a hydrophobic surface. The sample is handled using the sample affinity to the hydrophilic area, which facilitates simultaneous assay and isolation of microorganisms for culture operations and cloning.

WO 9955893 A retroviral vector comprising a retroviral envelope protein (REP) and at least one modified REP (mREP), with both REP and mREP including a surface protein to provide specific targeting and infectivity; used to introduce nucleic acid into eukaryotic cells, particularly for gene therapy.

WO 9955880 Newly isolated grapevine leafroll virus proteins or polypeptides useful for producing transgenic plants-including transgenic plant components - conferring viral disease resistance. The polynucleotides also form a method of detecting a viral nucleic acid molecule in a sample.

WO 9955883 Novel plant triacylglycerol lipase (TAGL) polynucleotides used to alter the level of the enzyme in transgenic plants. TAGL enzymes may be useful for the processing of plant seed oils, for the development of novel seed oils, and as targets to facilitate the design and identification of inhibitors of those enzymes that may be useful as herbicides.

US 5945577 An improved method of cloning nonhuman mammals using an activated nuclear transfer unit prepared from a differentiated mammalian cell or cell nucleus and an enucleated mammalian oocyte; useful for applications in human therapeutics and agriculture, including generation of cloned cells for transplantation and efficient production of biopharmaceuticals in transgenic animals.

\begin{tabular}{llll} 
Assignee & Author & Date & Status \\
Yang RC & Yang RC & $12 / 14 / 1999$ & A \\
& & & \\
$\begin{array}{l}\text { SmithKline Beecham } \\
\text { (London) }\end{array}$ & $\begin{array}{l}\text { Hodgson JE, } \\
\text { Wallis NG }\end{array}$ & $12 / 14 / 1999$ & A \\
\hline & & &
\end{tabular}

Japan Science \& Technology Corp.

Asztalos Z, Awano W,

$12 / 2 / 1999$

A2 (Kawaguchi, Japan) Lukacsovich T, Yamamoto D

Life Technologies

Gruber CE, Trinh TQ

$11 / 18 / 1999$

A1

(Rockville, MD)

SmithKline Beecham Thonnard J

$11 / 18 / 1999$

A2

Biologicals

(Rixensart, Belgium)

Hitachi Ltd. (Tokyo)

$11 / 5 / 1999$

A

Univ. Southern

Anderson WF,

$11 / 4 / 1999$

A1

California

(Los Angeles, CA)

Gordon EM, Hall FL

$11 / 4 / 1999$

Gonsalves D, Ling K

$11 / 4 / 1999$

A1

Foundation

(Ithaca, NY)

E.I. DuPont

de Nemours

(Wilmington, DE)

Cahoon EB, Cahoon RE, 11/4/1999

A2

Kinney AJ, Rafalski JA
Univ. Massachusetts (Amherst, MA)
Cibelli JB, Golueke PJ, 8/31/1999 Jerry DJ, Ponce de Leon FA, Robl J, Stice SL 